\title{
PEMANFAATAN TURBIN VENTILATOR DAN SISTEM PENCAHAYAAN BARU UNTUK MENINGKATKAN KESELAMATAN DAN KESEHATAN KERJA (STUDI KASUS IKM RANDANG KACANG)
}

\author{
Riko Ervil $^{1}$, Silfayona ${ }^{2}$ \\ ${ }^{1,2}$ Program Studi Teknik Industri Sekolah Tinggi Teknologi Industri Padang \\ Email: rikopdg@yahoo.com
}

\begin{abstract}
Randang Kacang is Small and Medium scale industries engaged in food. This industry have a standard of production, to meet the needs of consumers. This utilized manpower to expedite the process of production. The production process is carried out in the room that have higher temperature. And the production room that has not had a lighting system, workers can lead to carelessness causes accidents, so that workers are not comfortable in working. Therefore we need an increase in Occupational Health and Safety. So workers can work comfortably, healthy and safe during the production process. In this researched need to perform the installation of the turbine ventilator, aiming to stabilize room temperature in the production room, according to the Indonesian National Standard (SNI). Including to design of artificial lighting systems. Utilized TL bulbs (flourescent) in some point in the production process rooms to avoid the worker accidents. Installation of turbine ventilator performed at the top of the roof. At the top of the roof installed 2 turbine ventilator which has a diameter of 60 $\mathrm{cm}$. Turbine ventilator can absorb 200\% more air temperature. To reduce lack of lightening sistems utilized 18 watt Philips TL light bulbs (fluorescent) in 28 points according to SNI.
\end{abstract}

Keyword: Accident,Turbine Ventilator, SNI, Lighting Systems

\section{PENDAhUluan}

Industri Randang Kacang merupakan salah satu bentuk industri yang bergerak dibidang pengolahan pangan. Industri ini masih berskala Industri Kecil Menengah (IKM). IKM Randang Kacang merupakan industri yang berkembang, dan dapat memenuhi pesanan konsumen. Disamping itu IKM Randang Kacang juga mampu menyediakan tenaga kerja, sebagai sarana untuk memperlancar proses produksi.

Untuk memperlancar serta meningkatkan produksi dengan baik, pekerja harus mampu mengoperasikan serta menjalankan produksi dengan baik. Hal ini dengan memperhatikan standar mutu kacang yang telah ditetapkan oleh IKM Randang Kacang, dan juga harus memperhatikan keselamatan dan kesehatan kerja, agar terhindar dari kecelakaan kerja yang terjadi akibat kelalaian pekerja.

Kecerobohan para pekerja sering terjadi pada saat melakukan proses produksi. Tingginya angka kecelakaan kerja yang terjadi pada IKM Randang Kacang sehingga membuat pekerja merasa tidak nyaman dengan pekerjaan yang mereka lakukan.
Penanganan masalah kecelakaan kerja harus dilakukan secepat mungkin. Karena potensi kecelakaan kerja yang berbahaya dapat menimbulkan efek kerugian. Selain mencegah, setidaknya dapat mengurangi kecelakaan kerja. Oleh karena itu, diperlukan jaminan Keselamatan dan Kesehatan Kerja (K3), K3 merupakan suatu hal yang harus diwujudkan dalam bekerja. Agar pekerja merasa nyaman, sehat dan selamat dalam bekerja.

Diketahui pada kondisi ini IKM Randang Kacang memiliki suhu yang tinggi melebihi Nilai Ambang Batas (NAB) dalam ruang produksi dan tidak memiliki sistem pencahayaan. Sehingga hal ini akan mengakibatkan kecelakaan kerja bagi para pekerja. Pekerja merasa tidak nyaman dalam bekerja dengan adanya kecelakaan yang terjadi.

Memperhatikan uraian diatas maka dapat dirumuskan masalah yang melatarbelakangi penelitian ini yaitu:

1. Suhu pada ruang produksi pada IKM Randang Kacang tinggi melebihi nilai ambang batas. 
2. Tidak ditemukannya sistem pencahayaan dalam ruangan pada IKM Randang Kacang.

Sesuai dengan latar belakang diatas, tujuan penelitian ini adalah agar dapat melakukan pemasangan turbin ventilator untuk menstabilkan suhu pada ruang produksi pada IKM Randang kacang, dan merancang sistem pencahayaan yang baik pada IKM Randang Kacang.

\section{METODE}

Adapun jenis penelitian ini adalah penelitian survei yakni yang bertujuan untuk membuat komparasi atau evaluasi serta menggambarkan suatu yang sedang berlangsung pada saat penelitian dilakukan selama kurun waktu tertentu. Penelitian yang dilakukan dengan melakukan perbandingan yang telah tersedia dilapangan sesuai dengan keadaan apa adanya, serta memberikan saran kepada pemilik industri.

Dalam hal ini telah melakukan surver ke lokasi IKM Randang Kacang lokasi Kp Melayu Nagari Talu Kecamatan Talamau Kabupaten Pasaman Barat.

Ruang produksi IKM Randang Kacang merupakan ruangan yang digunakan untuk melakukan proses produksi, pada kondisi ruangan ini mencapai suhu $47{ }^{\circ} \mathrm{C}$, melebihi nilai ambang batas yang telah ditentukan. Pengukuran suhu dilakukan pada saat proses produksi berlangsung, dengan menggunakan thermometer ruangan, yang dilakukan dibeberapa titik lokasi.

Pengukuran suhu dilakukan dengan cara menggantungkan alat thermometer ruangan selama 2-5 menit disekitar ruangan yang akan diukur, kemudian air raksa atau alkohol yang digunakan sebagai bahan pengisi thermometer akan memuai atau menyusut sesuai dengan pana udara yang akan diukur, sehingga suhu udara dalam ruangan dapat dibaca dalam skala thermometer dalam derajat Celcius.

Sehingga dapat menyebabkan kecelakaan bagi para pekerjanya. Untuk mengurangi suhu atau panas yang ada diruang tersebut maka dilakukan pembuatan turbin ventilator yang terbuat dari aluminium, pemasangan turbin ventilator agar adanya sirkulasi udara dan dapat mengurangi panas pada saat produksi dilakukan. Turbin ventilator diletakkan pada kemiringan atap dengan diameter turbin 60 $\mathrm{cm}$.
Untuk menentukan jumlah ventilator yang diperlukan pada luas industri Randang Kacang, maka dapat digunakan rumus :

Jumlah Turbin

Ventilator $=\frac{\text { Volume ruangan }}{\text { (kap.sedot } x \text { waktu sirkulasi) }}$

Pada Industri Randang Kacang memerlukan sistem pencahayaan. Jika dilihat pada keadaan awal, industri randang kacang belum memiliki sistem pencahayaan. Pencahayaan hanya menggunakan cahaya matahari. Oleh karena itu perlu dilakukan pengukuran pencahayaan dengan menggunakan lux meter dengan cara sebagai berikut :

1. Menekan tombol on atau off untuk menyala dan mematikan.

2. Arahkan sensor cahaya dengan menggunakan tangan pada permukaan daerah yang akan diukur.

3. Kemudian akan terlihat hasil pengukuran pada layar panel.

4. Sebagai pengkalibrasi alat apabila terjadi error, maka dapat ditekan zero adjust VR.

Oleh sebab itu suatu penerangan dalam ruangan. Penerangan berupa pemasangan bola lampu, agar proses produksi dapat berjalan dengan lancar dikarenakan adanya pencahyaan yang sesuai standar.

Pemasangan bola lampu TL atau fluorescent atau dikenal juga lampu neon pada industri randang kacang dilakukan secara pararel, pemasangan bola lampu diberi jarak maksimal 3 meter, hal ini dilakukan agar industri randang kacang memiliki pencahyaan yang baik pada saat proses produksi dilakukan.

Untuk menentukan jumlah lampu yang harus dipasang, maka dapat menggunakan rumus:

$$
N=\frac{\text { Ex L xW }}{\emptyset \mathrm{xLLF} \times \mathrm{CU}_{\mathrm{x}} \mathrm{n}}
$$

Keterangan :

$\mathrm{N}=$ Jumlah titik lampu

$\mathrm{E}=$ Kuat Penerangan /target kuat penerangan yang akan dicapai (Lux)

$\mathrm{L}=$ Panjang Ruang(Meter)

$\mathrm{W}=$ Lebar Ruang (Meter)

$\varnothing=$ Total Lumen Lampu / Lamp Luminous

Flux

LLF $=$ Light loss factor $/$ Faktor Cahaya Rugi $(0,7-0,8)$ 
$\mathrm{CU}=$ Coeffesien of utilization / Faktor

Pemanfaatan $(50-65 \%)$

$\mathrm{n}=$ Jumlah Lampu dalam 1 titik Lampu

\section{HASIL PENELITIAN DAN PEMBAHASAN}

Pemasangan turbin ventilator bertujuan agar dapat mengurangi tingginya suhu atau panas disekitar ruang produksi yang mengakibatkan kecelakaan kerja. Untuk mengurangi panas ruangan maka perlu dilakukan pemasangan turbin ventilator. Agar berkurangnya panas dalam ruangan serta menghindari terjadinya kecelakaan kerja yang diakibatkan oleh panas dalam ruangan. Untuk pemasangan turbin ventilator dapat ditentukan dengan menggunakan rumus:

Jumlah turbin ventilator $=\frac{\text { volume ruangan }}{\text { kapasitas sedot } \mathrm{x} \text { waktu sirkulasi }}$

Dengan Panjang : $13 \mathrm{~m}$, Lebar : $8 \mathrm{~m}$ dan tinggi : $3 \mathrm{~m}$, untuk turbin ventilator dengan diameter $60 \mathrm{~cm}$ maka kapasitas sedot turbin ialah $30 \mathrm{~m} 3 /$ menit, dan memiliki waktu sirkulasi 10 menit.

Maka :

Jumlah turbin ventilator $=\frac{312 \mathrm{~m} 3}{30 \frac{\mathrm{m} 3}{\text { menit }} \times 10 \text { menit }}$

Jumlah turbin ventilator $=1,04$

Jadi untuk volume IKM Randang Kacang di perlukan 1,04 turbin ventilator jadi untuk IKM Randang Kacang dibuat 2 turbin ventilator. Turbin ventilator dipasang pada kemiringan atap atau posisi atas atap. Turbin ventilator akan diputar dengan bantuan angin tanpa memerlukan tenaga listrik.

1. Sistem pencahayaan pada industri randang kacang belum memiliki sistem pencahayaan. Kurangnya pencahayaan dalam ruangan mengakibatkan kecelakaan kerja. Sehingga perlu dilakukan pembuatan sistem pencahayaan buatan. Sistem pencahayaan yang dilakukan ialah pemasangan bola lampu pada IKM Randang Kacang. Pemasangan bola lampu berupa lampu TL (fluorescent), berbentuk vertikal dengan merk philips. Berdasarkan SNI 04-0225-2000, daya pencahayaan maksimum untuk ruang kantor atau industri adalah $15 \mathrm{Watt} / \mathrm{m}^{2}$. Sedangkan untuk luas yang dibutuhkan IKM Randang Kacang ialah dengan Panjang 10 meter dan Lebar 8 meter, jadi

$$
\begin{aligned}
\text { Luas } & =\text { Panjang } \times \text { Lebar } \\
\text { Luas } & =10 \text { meter } \times 8 \text { meter } \\
& =80 \mathrm{~m}^{2} .
\end{aligned}
$$

Jadi untuk menentukan titik pemasangan bola lampu dapat ditentukan dengan rumus : Diketahui $\mathrm{E}=200, \mathrm{~L}=10$ meter, $\mathrm{W}=8$ meter, $\emptyset=1098$ (untuk bola lampu 18 watt ),

Luminous Efficacy Lamp (LLF) $=0,8$, $\mathrm{CU}=65 \%$ dan $\mathrm{n}=1$

$$
\begin{aligned}
& \mathrm{N}=\frac{\text { ExL } \times \text { W }}{\emptyset \mathrm{xLF} \times \mathrm{CU} \times \mathrm{n}} \\
& \mathrm{N}=\frac{200 \times 10 \text { meter } \times 8 \text { meter }}{1098 \times 0,8 \times 65 \% \times 1} \\
& \mathrm{~N}=28 \text { titik lampu. }
\end{aligned}
$$

Menurut standart SNI, untuk penerangan industri tidak melebihi $15 \mathrm{~W} / \mathrm{m}^{2}$, maka :

$$
\begin{aligned}
& \text { Jumlah } W / \mathrm{m}^{2}=\frac{\text { jumlah titik lampu } x \text { watt lampu }}{\text { luas industri }} \\
& \text { Jumlah } W / \mathrm{m}^{2}=\frac{28 \times 18 \text { watt }}{80 \mathrm{~m}^{2}}
\end{aligned}
$$$$
\text { Jumlah } W / \mathrm{m}^{2}=6,3 \text { watt } / \mathrm{m}^{2}
$$

Jadi untuk luas ruangan sebesar $10 \times 8$ $\mathrm{m}^{2}$ diperlukan pemasangan lampu sebanyak 28 titik dengan dan daya 18 Watt dengan menggunakan lampu neon yang berbentuk vertikal dengan merk philips. Untuk penyebaran titik bola lampu dapat dipasang secara paralel.

\section{KESIMPULAN}

1. Pemasangan turbin ventilator pada Industri Kecil Menengah Randang Kacang dengan melakukan pemasangan 2 buah turbin ventilator pada bagian atas atap, turbin ventilator terbuat dari bahan aluminium dengan diameter $60 \mathrm{~cm}$ dan mampu mengisap udara panas $200 \%$ lebih banyak. Pemasangan turbin ventilator dilakukan agar adanya sirkulasi udara sehingga udara panas yang berada di ruang produksi dapat berkurang dan dapat terhindar dari kecelakaan kerja.

2. Perancangan sistem pencahayaan dilakukan agar dapat memudahkan pekerjaan yang dilakukan oleh pekerja, dengan adanya sistem pencahyaan yang baik maka akan mengurangi serta mencegah kecelakaan kerja yang disebabkan tidak adanya sistem pencahayaan. Perancangan sistem pencahayaan pada IKM Randang 
Kacang dilakukan dengan pemasangan bola lampu TL (fluorescent) dengan merk philips. Lampu philips dengan daya 18 Watt dan dipasang pada 28 titik yang tersebar dalam ruangan. Dengan jarak maksimal 3 meter dan dipasang secara pararel. Agar mencapai penerangan yang maksimum sesuai dengan SNI. Sehingga pekerja akan merasa nyaman dalam bekerja.

\section{DAFTAR KEPUSTAKAAN}

Direktorat Keselamatan dan Kesehatan Kerja. 2006. Pedoman Keselamatan Kesehatan Kerja di Ruang Terbatas (Confined Space ). Diakses pada 18 September 2012. Melalui situs (http://d.yimg.com/kq/ groups/1051902/1592620420/name/Ped oman+K3+di+Ruang+Terbatas.pdf)

Internasional Organization for Standarization (ISO) 9001:2000 tentang Penurunan Suhu Ruangan.

Keputusan Menteri Kesehatan No.1405 Tahun 2002 tentang Resiko Pencahayaan.

Keputusan Menteri Tenaga Kerja RI No. Kep 51/MEN/1999 tentang Nilai Ambang Batas Faktor Fisika di Tempat Kerja.

Menteri Tenaga Kerja. Surat Edaran No.Se.01/men/1978 Tentang Nilai ambang batas (NAB) untuk iklim Kerja dan nilai ambang batas (NAB) Untuk kebisingan di tempat kerja.1978.

Muhaimin. Teknologi Pencahayaan. PT Refika Aditama. Bandung. 2001.

Neris, A.,Ervil, R., Ernita,T., dan Nofriadiman. Buku Panduan Penulisan dan Ujian Skripsi. STTIND. Padang. 2011.

Nurdi,I. 2012. Fungsi Exhaust Fan untuk Kenyamanan. Diakses pada 18 September 2012.Melalui situs. (http://atjehpost.com/read/2012/06/13/1 1815/21/21/Fungsi-Exhaust-Fan-untukKenyamanan-Rumah-Anda)

Rifai, Ahmad. Desain Visual Display Pada Ruang Proses Produksi ( Studi Kasus PT Inti Vulkatama Padang). STTIND. Padang. 2011.

Smith,BJ.Peters,RJ.Owen, Stephen. Acoustic and Noise Control. Addison Wesley Longman Limited. England. 1996
Standar Nasional Indonesia 03-6575-2001 tentang Sistem Pencahayaan Ruangan.

Undang-Undang Nomor 1 Tahun 1970 tentang Keselamatan dan Kesehatan Kerja.

Undang-Undang Nomor 9 Tahun 1995 tentang Usaha Kecil Menengah. Undang-Undang Nomor 13 Tahun 2003 tentang Pengendalian Keselamatan dan Kesehatan Kerja. 
